\title{
Influence of presowing seed treatment on the yield of variegated alfalfa and eastern galega
}

\author{
S.I. Kokonov*, T.N. Ryabova, A.I. Votintsev, S.A. Mokeeva, S.L. Vorobyeva \& O.V. Esenkulova \\ Izhevsk State Agricultural Academy, Studencheskaya Street, 11, Izhevsk, 426069, Udmurt Republic, Russia \\ *Email: sergej-kokonov@yandex.ru
}

ARTICLE HISTORY

Received: 17 October 2020

Accepted: 20 February 2021

Published: 01 April 2021

\section{KEYWORDS}

Forage productivity

Plant development

Field germination

Wintering ability

Nodule bacteria
ABSTRACT

The article deals with the insufficiently studied problem of variegated alfalfa and eastern galega presowing seed treatment, which can serve as an excellent reserve for increasing their forage productivity. The quality of the seeds determines the stand density of perennial grasses and their yield. The studies have been performed on sod-podzolic medium loamy soil. The authors studied the effect of molybdenum-acid ammonium (300 gm/t), Rhizotorphine bacterial preparation (for variegated alfalfa - $0.5 \mathrm{l} / \mathrm{t}$, for eastern galega - $1.0 \mathrm{l} / \mathrm{t})$, HB-101 plant growth regulator $(1 \mathrm{ml} / \mathrm{t})$, and Agree's Forsage complex fertilizer $(1.2 \mathrm{l} / \mathrm{t})$ upon cultivating the studied crops. The consumption rate of the working solution (water + preparation) was 10 litres per ton of seeds. The accounting plot area was $33 \mathrm{~m}^{2}$. Perennial legumes were sown after spring rapeseed; the seeding rate for variegated alfalfa was 14 $\mathrm{kg} / \mathrm{ha}$, for eastern galega - $26 \mathrm{~kg} / \mathrm{ha}$. It has been found that introducing seed treatment with the Agree's Forsage complex fertilizer increases productivity by $23-47 \%$ due to increasing the field germination of variegated alfalfa by $10-15 \%$ and eastern galega by $4-10 \%$, and due to increasing the number of nodule bacteria by 6-13 per plant and 8-16 per plant respectively.

\section{Introduction}

Increasing productivity of field crops is the task that agrarians regularly perform. The use of plant growth regulators, complex fertilizers, biological preparations, and micronutrient fertilizers can serve as a reserve for solving this problem (1). Simultaneously, there are practically no such studies on the sod-podzolic soil of the region, which stipulates the necessity of research and development of production recommendations (2).

The agricultural production in the Udmurt Republic is focused on livestock breeding $(3,4)$ and a significant role in creating a solid forage base belongs to perennial herbs, the long growing season of which allows using them for hay and haylage, and for pasturing (5-7). The high productivity of perennial herbs and their conformity with the physiological needs of various animal species successfully combine with several valuable economic qualities: the high adaptability, the ability to thoroughly and rationally use the growing conditions, and the high resource- saving ability. Since they grow in the same location for several years, no annual costs are required for their cultivation $(8,9)$. Among perennial grasses in the region, mainly legumes are cultivated-cow clover, variegated alfalfa and eastern galega. At the same time, the issues of increasing productivity remain relevant.

Currently, biologically active compounds are widely used in many areas of the agricultural sector. Creating compounds with specified properties opens up tremendous possibilities for their use $(10,11)$. The effect of various stressful situations, such as adverse environmental factors and the effect of chemicals on the plants, may change the metabolism and even cause the death of the cells. To prevent oxidative stress and to reduce their effect, bio-antioxidants are widely used (12). Biologically active compounds help plants efficiently withstand low temperatures, lack of moisture, lack of nutrients in the soil, bacterization, and soil fungi. In this regard, it seemed extremely important to assess the effect of the preparations on

(c) Kokonov et al (2021). This is an open-access article distributed under the terms of the Creative Commons Attribution License, which permits unrestricted use, distribution and reproduction in any medium, provided the original author and source are credited (https://creativecommons.org/licenses/by/4.0/).

To cite this article: Kokonov S I, Ryabova T N, Votintsev A I, Mokeeva S A, Vorobyeva S L, Esenkulova O V. Influence of presowing seed treatment on the yield of variegated alfalfa and eastern galega. Plant Science Today. 2021;8(2):250-254. https://doi.org/10.14719/pst.2021.8.2.1000 
the germination of seeds of perennial leguminous herbs. All species of perennial legumes contain many hard seeds that do not germinate or slowly germinate in the year of sowing. Seed hardness is the seed coat impermeability to water, air and nutrients $(13,14)$. Some chemicals can significantly alter the nature of germination and substantially affect the biochemical characteristics of the developing seedling.

Sod-podzolic soil is inhabited with indigenous nodule bacteria of alfalfa (Medicago L.); their number varies from hundreds to millions of bacteria per $1 \mathrm{gm}$ of soil. They form numerous nodules with fairly high nitrogen-fixing activity on the host plant's roots; however, this activity may be significantly increased by using biological preparations of highly effective and competitive breeding strains of nodule bacteria for presowing inoculation of the seeds. The bacteria contribute to the optimal use of mineral and organic fertilizers. Propagating in the root zone, they protect them from the penetration of microflora that causes plant diseases. The most common nitrogen-fixing symbiotic bacteria in the production of inoculants belong to the Rhizobium genus. In the form of biological preparations, they enhance the fixation of the atmospheric nitrogen, increase the uptake of nitrogen from mineral fertilizers and soil, stimulate the growth and development of the plants and accelerate crop ripening (15).

The use of complex micronutrient fertilizers, growth regulators, and the Baikal EM-1 biological product for spring triticale crops was economically beneficial. They increased its yield and grain quality, given the low cost of preparations and low consumption rates (16). Seed and crop treatment with micronutrient fertilizers, growth regulators and the Baikal EM-1 biological product in the technology of cultivating spring triticale on leached black soil of the Penza region allowed activating growth and production, increasing the crop yield by $0.28 \mathrm{t} / \mathrm{ha}$ (11.1\%) and improving the grain quality. The preparations increased the total amount of amino acids by $1.9-27.5 \%$, compared to the reference. Out of 12 studied preparations used for pre-sowing seed treatment, Zircon plant growth regulator showed the lowest seed treatment efficiency, while Baikal M1 + Poly-Feed demonstrated the highest one (16).

Based on the foregoing, a conclusion can be made about the effectiveness of presowing treatment of the seeds of field crops. There have been almost no studies of using liquid complex and biological fertilizers, plant growth regulators in cultivating variegated alfalfa and eastern galega on sod-podzolic soils of the Middle Urals and such studies remain very relevant. The research has been aimed at studying the effectiveness of variegated alfalfa and eastern galega seed treatment in their cultivation for fodder.

\section{Materials and Methods}

The studies were performed during 2017, 2018 and 2019 growing seasons at the educational and scientific production complex (ESPC-Agrotechnopark) of the Izhevsk State Agricultural Academy. The indicators were determined in accordance with the guidelines for field experiments with forage crops (17).

The object of the research was variegated alfalfa (Medicago varia Mart.), Nakhodka cultivar and eastern galega (Galega orientalis Lam.), Gale cultivar. As part of the research, the agrochemical characterization of soils was performed annually according to the methods presented in the guidelines for the comprehensive monitoring of soil fertility of agricultural lands (18). All studies and observations were carried out in triplicate annually.

The soil of the experimental plot was sodpodzolic medium loamy soil with the following agrochemical characteristics of the arable layer: humus content $2.3-2.9 \%$, mobile phosphorus 232-282 $\mathrm{mg} / \mathrm{kg}$ of soil, mobile potassium $109-252 \mathrm{mg} / \mathrm{kg}$. The exchange acidity of the soil was slightly acidic and close to neutral (pH 5.3-5.9).

The scheme of the experiment included the following variants: (i) without seed treatment (reference), (ii) treatment with molybdenum-acid ammonium (the recommended consumption rate of the preparation (active ingredient constituted 52\%) was $300 \mathrm{gm} / \mathrm{t}$, when processing seeds of perennial grasses) (Buisk chemical plant, Russia), (iii) treatment with the Rhizotorphine bacterial preparation $(0.5 \mathrm{l} / \mathrm{t}$ for variegated alfalfa, $1.0 \mathrm{l} / \mathrm{t}$ for eastern galega in accordance with the manufacturer's recommendations) (Biofabrika LLC, Russia), (iv) treatment with the HB-101 plant growth regulator (1 $\mathrm{ml} / \mathrm{t})$ (Japan), and (v) treatment with the Agree's Forsage complex fertilizer (1.2 l/t) (Soyuzkhim LLC, Russia). The consumption rate of the working solution was 10 litres per ton of seeds. Seeds were treated directly before sowing. The accounting plot area was $33 \mathrm{~m}^{2}$; the experiment was performed in triplicate. Perennial legumes were sown after spring rapeseed; the seeding rate for variegated alfalfa was $14 \mathrm{~kg} / \mathrm{ha}$ for eastern galega - $26 \mathrm{~kg} / \mathrm{ha}$.

Statistical data processing was performed using the variance analysis method. The significance of the difference between the means was analyzed using the least significant difference, which was recognized as significant at a $5 \%\left(\mathrm{LSD}_{05}\right)$ level of significance in this experiment.

\section{Results and Discussion}

The density of stalks and the number of plants per unit area determines the yield of any crop. This requires ensuring high field germination. Variegated alfalfa seed treatment before sowing ensured a relatively high standing density of the seedlings. On average for 2017-2019, the significantly high field germination was promoted by treating the seeds with the Agree's Forsage complex fertilizer (77\%), which was $10-15 \%$ higher than the field germination of the seeds in the other studied variants (Table 1).

In 2017, low field germination of the seeds of eastern galega (25-41\%) was noted. One of the reasons was the formation of a soil crust due to heavy rains during the seeds-to-sprouts period when 
a $207 \%$ increase over the normal rainfall occurred. The presowing seed treatment with the HB-101 plant growth regulator and the Agree's Forsage complex fertilizer significantly increased the field germination of the seeds of eastern galega by $11-16 \%\left(\mathrm{LSD}_{05}=5 \%\right)$. A similar pattern was observed in the crops during 2018 and 2019. Over the three years of the studies, presowing seed treatment with the NV-101 plant growth regulator and the Agree's Forsage complex fertilizer had ensured the highest seed germination of $47-50 \%$, which was $4-10 \%$ higher than in the other studied variants.

The plant wintering ability is critical in the formation of fodder productivity of perennial herbs. The worst wintering ability of variegated alfalfa (51$55 \%$ ) was noted after sowing the untreated seeds (Table 2). Seed preparation for sowing contributed to increasing their wintering ability by $8-22 \%\left(\mathrm{LSD}_{05}=\right.$ $7 \%$ ) in the second year of life. The prolonged action of
For the formation of nodules on the plant roots in the initial period of vegetation and active fixation of nitrogen, prolonged active symbiosis, and ultimately, the maximum amount of nitrogen fixed from the air, active and competitive nodule bacteria are needed. All variants of seed treatment before sowing contributed to the formation of a significantly increased number of nodules on the roots of variegated alfalfa: in $201710-13$ per plant $\left(\mathrm{LSD}_{05}=4\right.$ per plant), in $20186-9$ per plant (LSD $05=4$ per plant), in 2019 10-11 per plant ( $\mathrm{LSD}_{05}=6$ per plant), except for the variant where the seeds were treated with molybdenum-acid ammonium (Table 3).

On average, over the three years, variegated alfalfa seed treatment with the Rhizotorphine bacterial preparation, the HB-101 plant growth regulator, and the Agree's Forsage complex fertilizer had increased the number of bacteria on the nodules by $30-33 \%$.

Table 1. The field germination of variegated alfalfa and eastern galega, depending on the presowing seed treatment \%.

\begin{tabular}{|c|c|c|c|c|c|c|c|c|}
\hline \multirow{2}{*}{ Presowing seed treatment } & \multicolumn{4}{|c|}{ Variegated alfalfa } & \multicolumn{4}{|c|}{ Eastern galega } \\
\hline & 2017 & 2018 & 2019 & average & 2017 & 2018 & 2019 & average \\
\hline $\begin{array}{l}\text { Without treatment } \\
\text { (reference) }\end{array}$ & 45 & 72 & 68 & 62 & 25 & 39 & 55 & 40 \\
\hline $\begin{array}{l}\text { Molybdenum-acid } \\
\text { ammonium }\end{array}$ & 55 & 71 & 70 & 65 & 26 & 40 & 57 & 41 \\
\hline Rhizotorphine & 55 & 77 & 68 & 67 & 29 & 40 & 59 & 43 \\
\hline $\begin{array}{l}\text { The NV-101 plant growth } \\
\text { regulator }\end{array}$ & 54 & 76 & 72 & 67 & 36 & 44 & 62 & 47 \\
\hline $\begin{array}{l}\text { The Agree's Forsage } \\
\text { complex fertilizer }\end{array}$ & 82 & 77 & 73 & 77 & 41 & 47 & 63 & 50 \\
\hline $\mathrm{LSD}_{05}$ & 8 & 4 & 5 & & 5 & 4 & 6 & \\
\hline
\end{tabular}

Table 2. The wintering ability of variegated alfalfa and eastern galega, depending on the presowing seed treatment \%.

\begin{tabular}{|c|c|c|c|c|}
\hline \multirow[b]{2}{*}{ Presowing seed treatment } & \multicolumn{2}{|c|}{ Variegated alfalfa } & \multicolumn{2}{|c|}{ Eastern galega } \\
\hline & $\begin{array}{l}\text { the second year of } \\
\text { life }\end{array}$ & the third year of life & $\begin{array}{l}\text { the second year of } \\
\text { life }\end{array}$ & the third year of life \\
\hline Without treatment (reference) & 55 & 51 & 49 & 84 \\
\hline Molybdenum-acid ammonium & 66 & 60 & 48 & 84 \\
\hline Rhizotorphine & 70 & 63 & 60 & 86 \\
\hline The NV-101 plant growth regulator & 77 & 66 & 59 & 88 \\
\hline The Agree's Forsage complex fertilizer & 63 & 63 & 59 & 88 \\
\hline $\mathrm{LSD}_{05}$ & 7 & 6 & 4 & $\mathrm{~F}_{\text {act. }}<\mathrm{F}_{05}$ \\
\hline
\end{tabular}

the studied products was noted, as evidenced by the significant effect of presowing seed treatment on the wintering ability of variegated alfalfa. Winter hardiness of the plants increased by $9-15 \%\left(\mathrm{LSD}_{05}=\right.$ $6 \%$ ) due to better development of the root system of crops and the accumulation of plastic substances in the root collar.

The wintering ability of eastern galega in the second year of life was 48-60\%. Presowing seed treatment contributed to a significant increase in the winter hardiness of eastern galega, as evidenced by an increased wintering ability by $10-11 \%$ after using the Rhizotorphine bacterial preparation, the HB-101 plant growth regulator and the Agree's Forsage complex preparation $\left(\mathrm{LSD}_{05}=4 \%\right)$.

The wintering ability of eastern galega plants in the third year of life in the experimental variants was high (83-88\%). Due to the roots, the eastern galega stand renews itself every year. In this regard, in the third year of life, the effect of presowing seed treatment in the experiment's variants levelled out, and the stand restored.
It was found that pre-sowing seed treatment had a positive effect on the formation of nitrogen-fixing nodules on the roots of eastern galega. Their analysis in the budding phase of the plants showed that, in 2017 all the studied variants of eastern galega seeds, except for the variant with molybdenum-acid ammonium, contributed to a significant increase in the number of nodules, $8-20$ per plant $\left(\mathrm{LSD}_{05}=4\right.$ per plant). Increase in the number of nodules on the roots of eastern galega, unlike the variant without seed treatment, was by 3-18 pieces/plant in 2018 and by 7-23 pieces/plant in 2019. A significant increase in the number of nodules was recorded in 2018 when the seeds were treated with Agree's Forsage complex fertilizer (18 pieces/plant), and in 2019, when the seed treatment was performed with HB-101 plant growth regulator (23 pieces/plant). On average, over the three years of the studies, pre-sowing seed treatment had increased the number of nitrogen-fixing bacteria on the roots of eastern galega by $22-78 \%$, which evidenced of the different effect of the studied preparations on the development of microorganisms on plant roots and legume-rhizobial symbiosis. 
Table 3. The number of nodules on the roots of the plants of variegated alfalfa and eastern galega, depending on the presowing seed treatment, nodules per plant.

\begin{tabular}{|c|c|c|c|c|c|c|c|c|}
\hline \multirow{2}{*}{$\begin{array}{l}\text { Presowing seed } \\
\text { treatment }\end{array}$} & \multicolumn{4}{|c|}{ Variegated alfalfa } & \multicolumn{4}{|c|}{ Eastern galega } \\
\hline & 2017 & 2018 & 2019 & average & 2017 & 2018 & 2019 & average \\
\hline $\begin{array}{l}\text { Without treatment } \\
\text { (reference) }\end{array}$ & 28 & 33 & 29 & 30 & 19 & 21 & 15 & 18 \\
\hline $\begin{array}{l}\text { Molybdenum-acid } \\
\text { ammonium }\end{array}$ & 31 & 36 & 30 & 32 & 19 & 24 & 22 & 22 \\
\hline Rhizotorphine & 39 & 39 & 39 & 39 & 39 & 34 & 23 & 32 \\
\hline $\begin{array}{l}\text { The NV-101 plant } \\
\text { growth regulator }\end{array}$ & 41 & 41 & 39 & 40 & 27 & 31 & 38 & 32 \\
\hline $\begin{array}{l}\text { The Agree's Forsage } \\
\text { complex fertilizer }\end{array}$ & 38 & 42 & 40 & 40 & 32 & 39 & 22 & 31 \\
\hline $\mathrm{LSD}_{05}$ & 4 & 4 & 6 & & 4 & 14 & 15 & \\
\hline
\end{tabular}

Density of stalks and the activity of the symbiotic apparatus due to seed treatment had an effect on the fodder productivity of variegated alfalfa and eastern galega. Table 4 shows the average yield of the dry matter after two mowings in two plots. The studied preparations for pre-sowing seed treatment ensured a significant increase in the dry matter yield of variegated alfalfa. Moreover, this increase was noted in the crops during the second and the third years of life. On average for the experiment, in the second year of life, the increase amounted to 1.9-2.5 t/ha, or $22-28 \%\left(\mathrm{LSD}_{05}=0.5 \mathrm{t} / \mathrm{ha}\right)$, in the third year of life - to 2.3-3.1 $\mathrm{t} / \mathrm{ha}$, or $23-30 \%\left(\mathrm{LSD}_{05}=0.6 \mathrm{t} / \mathrm{ha}\right)$, compared
The data obtained were similar to the results of previous studies with plant growth regulators. The effectiveness of growth regulators was established on leached black soils of Russia, as evidenced by an increase in the seed productivity of the eastern galega by $55.3 \%$ (19). Studies performed in India demonstrated the increase in pea yield by $19 \%$ when using a plant growth regulator (20).

The presowing seed treatment of variegated alfalfa and eastern galega with the Rhizotorphine bacterial preparation, the HB-101 plant growth regulator and the Agree's Forsage complex fertilizer increased the field germination rate of variegated

Table 4. The variegated alfalfa and eastern galega dry matter yield, depending on pre-sowing seed treatment $\mathrm{t} / \mathrm{ha}$.

\begin{tabular}{lcccc}
\hline \multirow{2}{*}{ Presowing seed treatment } & \multicolumn{2}{c}{ Variegated alfalfa } & \multicolumn{2}{c}{ Eastern galega } \\
\cline { 2 - 5 } & the second year of life & the third year of life & the second year of life & the third year of life \\
\hline Without treatment (reference) & 8.6 & 10.1 & 7.8 & 10.5 \\
\hline Molybdenum-acid ammonium & 10.6 & 12.7 & 7.9 & 11.1 \\
\hline Rhizotorphine & 10.5 & 12.4 & 11.0 & 12.1 \\
\hline The NV-101 plant growth regulator & 10.8 & 12.8 & 10.7 & 12.7 \\
\hline The Agree's Forsage complex fertilizer & 11.1 & 13.2 & 11.5 & 12.9 \\
\hline LSD $_{05}$ & 0.5 & 0.6 & 1.0 & 1.8 \\
\hline
\end{tabular}

to this indicator in the reference. The maximum dry matter yield in the second year of life was $11.1 \mathrm{t} / \mathrm{ha}$, and in the third year of life, the yield of $13.2 \mathrm{t} / \mathrm{ha}$ was obtained after presowing seed treatment with the Agree's Forsage complex fertilizer.

The Rhizotorphine bacterial preparation for presowing seed treatment, the HB-101 plant growth regulator and the Agree's Forsage complex fertilizer significantly increased the yield of dry matter of eastern galega in the second year of life by $2.9-3.7$ $\mathrm{t} / \mathrm{ha}$, compared to the yield in the reference variant with $\mathrm{LSD}_{05}=1.0 \mathrm{t} / \mathrm{ha}$. On average, for the experiment, the yield of crops of the third year of life was higher by $25 \%$, compared to the crops of the second year of life due to the development of a taproot system with suckers, which allowed the plants to self-reproduce vegetatively. In the variant without seed treatment, the dry matter yield of eastern galega of the third year of life amounted to 10.5 t/ha. A significant increase in the dry matter yield by $2.2-3.4 \mathrm{t} / \mathrm{ha}$ was noted in the variants with presowing seed treatment with the HB-101 plant growth regulator and the Agree's Forsage complex fertilizer with $\mathrm{LSD}_{05}=1.8$ $\mathrm{t} /$ ha. The maximum yield of eastern galega dry matter (11.5-12.9 t/ha) was obtained in the variant with pre-sowing seed treatment of Agree's Forsage complex fertilizer. alfalfa and eastern galega by $5-15 \%$ and $3-10 \%$, respectively; the number of nodule bacteria on the roots increased by 9-10 per plant and 13-14 per plant respectively. The dry matter accumulation increased by $23-31 \%$ and $21-41 \%$ respectively.

\section{Conclusion}

Studies of variegated alfalfa and eastern galega presowing seed treatment with the HB-101 plant growth regulator and Agree's Forsage complex fertilizer have been performed for the first time on sod-podzolic soils of the Udmurt Republic. Study of modern preparations aimed at an increase in the forage productivity of crops is a promising area of further research.

Three-year field experiments enable drawing the following conclusions. Variegated alfalfa and eastern galega presowing seed treatment allow for increasing field germination rate of seeds, wintering ability and the nodule bacteria development. Due to better legume-rhizobial symbiosis and optimal density of stalks, the studied crops showed higher forage productivity than the variant of sowing without seed treatment. The highest dry matter accumulation in variegated alfalfa (11.1-13.2 t/ha) and eastern galega (11.5-12.9 t/ha) was obtained 
when treating the seeds with Agree's Forsage complex fertilizer, which was 23-47 \% higher than in the variant without seed treatment due to increase in the field germination of seeds, wintering ability of plants, improved legume-rhizobial symbiosis; thus, this variant of treatment could be recommended for agricultural production.

In order to create a stable agrocenosis of eastern galega and variegated alfalfa on sod-podzolic soil and increase productivity for agricultural producers, it is recommended to use the HB-101 plant growth regulator $(1 \mathrm{ml} / \mathrm{t})$ and the Agree's Forsage complex fertilizer $(1.2 \mathrm{l} / \mathrm{t})$.

\section{Authors' contributions}

All authors contributed equally.

\section{Conflict of interests}

Authors do not have any conflict of interests to declare.

\section{References}

1. Ryabova TN, Votintsev AI, Kokonov SI. Forage productivity of bastard alfalfa as affected by cover crop and seed treatment. Fodder Journal. 2020;6:16-19.

2. Mokeeva SA, Kokonov SI, Ryabova TN. Development and productivity of eastern galega during sowing seed treatment. Vestnik of Ulyanovsk State Agricultural Academy. 2020 2(50):47-53. https://doi.org/10.18286/1816-4501-2020-2-47-53

3. Kokonov SI, Nikitin AA. Forage productivity of Sudan grass agrocenoses with grain legumes, depending on the time of harvesting. Achievements of Science and Technology in the AIC. 2017;31(4):72-74.

4. Kislyakova E, Berezkina G, Vorobyeva S, Kokonov S, Strelkov I. Influence of using seeds of flax and raps in cow rates on the quality of milk and dairy products. Bulgarian Journal of Agricultural Science. 2019;25(1):129-33.

5. Zubarev YN, Falaleeva LV, Subbotina YV, Nechunaev MA. Eastern galega - the crop of the XXI century. The Perm Agrarian Bulletin. 2016;4(16):4-9.

6. Nelyubina ZhS, Kasatkina NI. Analysis of long-term cultivation of the agrophytocenoses of perennial herbs in the conditions of the Udmurt Republic. Achievements of Science and Technology in the AIC. 2014;4:57-60.

7. Kokonov SI, Temkin I, Babaytseva T, Vafina EF. Agroecological assessment of perennial ryegrass varieties in the conditions of the Udmurt Republic. Digital agriculture - development strategy. Proceedings of the International Scientific and Practical Conference (ISPC 2019). Advances in Intelligent Systems Research, 2019;254-57. https://doi.org/10.2991/ispc19.2019.57

8. Kshnikatkina AN, Alenin PG, Kshnikatkin SA. Agroecological assessment of eastern galega as a predecessor. Niva Povolzhya. 2012;1(22):24-31.

9. Ledyaeva NV. The efficiency of cultivating variegated alfalfa in the mid-mountain zone of the Altai Republic. News of the Altai State Agrarian University. 2016;8(142):10-15.

10. Kshnikatkina AN, Kshnikatkin SA, Denisov KE, Denisov EP, Chetverikov FP, Poletaev IS. Complex water-soluble fertilizers, growth regulators and bacterial preparations in the technology of spring triticale cultivation. The Agricultural Scientific Journal. 2017;4:27-32.

11. Isaichev VA, Andreev NN, Kaspirovskij AV. Specific features of dynamic patterns of microelement in spring wheat plants when applying growth regulators in the technology of cultivation. Research Journal of Pharmaceutical, Biological and Chemical Sciences. 2019;10(3):137-42.

12. Turkova EV. The morphophysiological peculiarities of shoots formation in perennial leguminous herbs. Agricultural Sciences and the AIC at the turn of the century. 2015;11:7-14.

13. Orazbayev S, Salakshinova B, Mendibaeva G, Alipbekov K. The effect of scarification on perennial leguminous herb seed hardness. The International Research Journal. 2013;12(2):14 16.

14. Khadeev TG, Lapina MS. The methods of increasing alfalfa field germination. Protection and Quarantine of Plants. 2012;6:26-27.

15. Atlasova LG. Symbiotic activity of the Medicago falcata nodule bacteria in the conditions of Central Yakutia. News of the Samara Scientific Center of the Russian Academy of Sciences. 2015;5(17):77-80

16. Kshnikatkina AN, Alenin PG, Kshnikatkin SA. The yield and quality of hulless barley under foliar fertilization with microelement fertilizer in conditions of forest-steppe of the Middle Volga region. Research Journal of Pharmaceutical, Biological and Chemical Sciences. 2018;9(2):90-94.

17. Guidelines for Conducting Field Experiments with Forage Crops. Moscow: Russian Academy of Agricultural Sciences; 1997. $156 \mathrm{p}$.

18. Guidelines for the comprehensive monitoring of soil fertility of agricultural lands Moscow region: FGNU "Rosinformagrotech"; 2003. $240 \mathrm{p}$.

19. Eryashev AP, Timoshkin OA, Kshnikatkina AN. The efficiency of eastern galega (Galega orientalis) cultivation. International Journal on Emerging Technologies. 2020;11(2):910-14.

20. Sumathi A, Babu Rajendra Prasad V, Vanangamudi M. Influence of plant growth regulators on yield and yield components in pigeon pea. Legume Research. 2018;41(3):392-98. 